\title{
Estrogen Receptor Measurement
}

National Cancer Institute

\section{Source}

National Cancer Institute. Estrogen Receptor Measurement. NCI Thesaurus. Code C112274.

The determination of the amount of estrogen receptor present in a sample. 